\title{
HUBUNGAN KOMITMEN ORGANISASI DENGAN KINERJA PADA GURU PENDIDIK KHUSUS HONORER (GPK) DI KOTA PADANG
}

\author{
Riris Wisuda Tumanggor, Krisnova Nastasia \\ Universitas Putra Indonesia "YPTK" Padang \\ Email : riristumanggor500@gmail.com, krisnova88@ gmail.com
}

\begin{abstract}
This research was conducted on Inclusive Special Educator Teachers (GPK) in Padang City. The purpose of this study was to determine the relationship between Organizational Commitment and the work performance of Inclusive Honorer (GPK) Teachers in Padang City. The sample selection technique in this study uses saturated sampling which is the method of determining the sample if the population is relatively small, less than 30 people, or research that wants to generalize with a very small error Sugiyono (2017). The sample in this study amounted to 86 people. Validity and reliability test using Cronbach Alpha. The test results show the validity coefficient on the Organizational commitment scale 0.408 to 0.695 while the reliability coefficient is 0.982 . The test results of the performance scale validity coefficient showed from 0.343 to 0.682 with a reliability coefficient of 0.948 . Hypothesis test results show the magnitude of the correlation coefficient of 0.487 with a significant level of $p=0,000$. It means that it can be concluded that there is a significant relationship between organizational commitment and performance. Positive values indicate that the higher the organizational commitment, the higher the teacher's performance, and vice versa, the lower the organizational commitment, the lower the performance of Teachers of Special Education Teachers (GPK). The effective contribution of the compensation variable to job satisfaction is $49 \%$
\end{abstract}

Keywords: Job Satisfaction, Compensation, Teacher Special Educators (GPK)

\begin{abstract}
Abstrak
Penelitian ini dilakukan pada Guru Pendidik Khusus (GPK) Inklusif di Kota Padang. Tujuan penelitian ini adalah untuk mengetahui hubungan antara Komitmen Organisasi dengan kinerja kerja Guru Pendidik Khusus Honorer (GPK) Inklusif di Kota Padang. Teknik pemilihan sampel dalam penelitian ini menggunakan sampling jenuh yaitu yaitu cara penentuan sampel bila jumlah populasi relatif kecil,kurang dari 30 orang,atau penelitian yang ingin membuat generelisasi dengan kesalahan yang sangat kecil Sugiyono (2017) . Sampel dalam penelitian ini berjumlah 86 orang. Uji validitas dan reliabilitas menggunakan Alpha Cronbach.Hasil uji coba menunjukkan koefisien validitas pada skala komitmen Organisasi 0,408 sampai 0,695 sedangkan koefisien reliabilitasnya sebesar 0,982. Hasil uji coba koefisien validitas skala kinerja menunjukkan dari 0,343 sampai 0,682 dengan koefisien reliabilitasnya sebesar 0,948. Hasil uji hipotesis menunjukkan besarrya koefisien korelasi sebesar 0,487 dengan taraf signifikan $\mathrm{p}=0,000$ Artinya dapat disimpulkan bahwa terdapat hubungan yang signifikan antara komitmen organisasi dengan kinerja . Nilai positif menunjukkan bahwa semakin tinggi komitmen organisasi maka semakin tinggi kinerja guru, begitu juga sebaliknya semakin rendah komitmen organisasi maka semakin rendah kinerja Guru Pendidik KhususHonorer (GPK). Adapun sumbangan efektif dari variabel kompensasi terhadap kepuasan kerja sebesar 49\%
\end{abstract}

Kata kunci: Kepuasan Kerja, Kompensasi, Guru Pendidik Khusus (GPK)

\section{Pendahuluan}

Pendidikan merupakan kebutuhan manusia sepanjang hidupnya. Pendidikan selalu mendapatkan perhatian dari seluruh Bangsa dan Negara, sebab pendidikan menemukan kualitas sumber daya manusia yang dapat membangun bangsa dan negara untuk mencapai 
tujuan.Pendidikan formal yaitu pendidikan yang didapatkan melalui sekolah merupakan pendidikan yang harus didapatkan oleh anak didik. Anak yang harus mendapatkan pendidikan formal bukan hanya anak yang mempunyai kemampuan atau anak normal. Anak yang mempunyai kemampuan khusus (ABK) dan anak berbakat juga harus mendapatkan pendidikan sama halnya dengan anak normal (Khoiriyahdalam Pratiwi, 2015) ${ }^{[10]}$. Guru memiliki peran yang sangat besar dalam pencapaian kualitas pendidikan secara umum. Kondisi ini dimungkinkan karena posisi guru yang sangat dominan dalam berinteraksi dengan peserta didik dalam proses pembelajaran. Standar guru adalah suatu ukuran yang ditetapkan atau dipersyaratkan dalam bentuk penguasaan pengetahuan dan berprilaku layaknya seorang guru untuk menduduki jabatan fungsional sesuai bidang tugas, kualifikasi dan jenjang pendidikan. Keberadaan sekolah tidak hanya penting bagi anak normal, melainkan bermanfaat pula untuk manak berkebutuhan khusus yang memiliki keterbatasan dan kekurangan ketika harus berinteraksi dengan orang lain (Zakia, 2015). ${ }^{[11]}$. Amir (dalam Fatmawati \& Pane, 2017) menyatakan kinerja adalah perilaku atau kegiatan yang ditampilkan oleh seseorang dalam kaitannya dengan tugas kerja di perusahaan, departemen, atau organisasi yang dilaksanakan sesuai dengan potensi yang dimilikinya. ${ }^{[7]}$. Menurut Mangkunegara(dalam Ahmad 2017) terdapat 2 faktor yang dapat mempengaruhi kinerja guru yaitu faktor kemampuan dan faktor motivasi. Menurut Gibson, dkk (dalam Priansa, 2017) ada tiga kelompok variabel yang mempengaruhi perilaku kerja dan kinerja yaitu variabel individu,variabel organisasi,variabel psikologis.

${ }^{[4]}$. Kinerja pegawai yang baik juga tentunya dapat mendorong tercapainya tujuantujuan organisasi. Itulah sebabnya mengapa kinerja pegawai sangat penting untuk kemajuan sebuah organisasi atau instansi. Hal ini dipertegas oleh pernyataan Sinambela (dalam Priansa, 2017) menyatakan bahwa kinerja adalah kemampuan pegawai dalam melakukan keahlian tertentu. Kinerja pegawai sangatlah perlu sebab dengan kinerja ini akan diketahui seberapa jauh kemampuan pegawai dalam melaksanakan tugas yang dibebankan kepadanya.

Berdasarkan wawancara awal yang dilakukan oleh peneliti pada 29 September 2018, diperoleh keterangan bahwa Guru Pendidik Khusus mengajar sudah berkisar antara 2 hingga 15 tahun. ) diperoleh keterangan bahwa Guru Pendidik Khusus saat ini merasa kurang optimal dalam melakukan pekerjaannya,misalnya dalam proses mengajar GPK tidak lagi bisa memberikan materi pembelajaran secara lengkap atau sesuai dengan rancangan pembelajaran kepada muridnya selain itu GPK sering mengabaikan proses evaluasi perkembangan setiap anak muridnya ,yang mana hal tersebut seharusnya dilaksanakan setiap minggu oleh GPK dengan rutin namun saat ini tidak lagi terlaksana dengan rutin karena harus membagi waktu dengan kerja yang lain. Menurut mereka selama menjadi guru pendidik khusus dan memiliki peranan ganda disekolah mereka mulai lalai dalam mengerjakan tugas yang seharusnya menjadi kewajiban guru pendidik khusus, mereka jadi tidak tepat waktu dalam membuat laporan tentang perkembangan anak berkebutuhan khusus,tidak memiliki waktu yang cukup untuk membuat RPP (Rancangan Program Pembelajaran) sehingga sering terlambat dalam menyerahkan RPP, dan mereka juga sering terlambat dalam memulai jam mengajar di lokal ABK karena masih mengurus pekerjaan yang lain. Selain itu mereka juga mengungkapkan kurangnya kepedulian sesama pegawai sehingga mereka jarang bisa untuk saling membantu

Banyaknya guru juga berperan ganda di sekolah dalam menjalankan pekerjaanya misalnya menjadi guru bidang studi sebagai guru pengajar mata pelajaran lain dan banyak menjadi wali kelas. Dengan hal tersebut Tentu saja, GPK tidak fokus pada tanggung jawab pada Anak Berkebutuhan Khusus (GPK) saja disekolah, namun akan mempunyai pekerjaan lain sebagai pekerjaan tambahan untuk memperoleh gaji tambahan dari yang seharusnya diterima dan berefek dengan terabaikan nya anak didik sehingga progres dalam selama di sekolah reguler belum terpenuhi secara baik. Seharusnya terjadi dalam sekolah reguler, Anak Berkebutuhan Khusus (ABK) akan mampu mandiri dan kemajuan yang lebih baik disekolah 
umum, hal tersebut tentu dengan pengawasan yang baik dari guru pendidik khusus (GPK). Guru Pendidik Khusus (GPK) dalam pekerjaannya, tentunya mereka tidak memiliki kenyaman lagi dalam bekerja dengan mengajar di luar tanggung jawabnya. Selain itu GPK (guru pendidik khusu) juga mengatakan adanya penundaan pembuatan tugas yang seharusnya mereka kerjakan dimana setiap bulannya adanya laporan evaluasi perkembangan anak namun harus tertunda karena terbaginya waktu dengan pekerjaan yang lain. Guru Pendidik Khusus (GPK) bertahan karena iming-iming pengakatan Pegawai Negeri Sipil (PNS) setelah mengabdi selama kurang lebih 12 tahun di sekolah, selain itu yang menjadi alasan alasan lain mereka bertahan sebagai Guru Pendidik Khusus (GPK) dikarekan sulitnya mencari pekerjaan lain dan peluang pekerjaan yang sulit didapatkan dengan wilayah yang sama. Apalagi yang terjadi saat ini, umumnya setiap perusahaan akan merekrut karyawan dengan batas umur. Kenyataannya kebanyakan Guru Pendidik Khusus (GPK) tersebut telah melewati batas umur yang kebanyakan perusahaan tentukan. Untuk menjadi Pegawai Negeri Sipil (PNS) juga tidak mudah didapatkan dengan pesaing dan jumlah guru yang mulai banyak. Mereka juga takut jika nanti mereka tidak lagi bekerja sebagai GPK gaji yang mereka dapatkan tidak sama dengan pekerjaan yang lama Namun ada juga yang mengatakan bahwa mereka bertahan sampai saat ini karena keinginan dari diri mereka sendiri,keikhlasan serta mempunyai kesenangan tersendiri ketika bisa mendidik anak-anak yang berkebutuhan khusus dan jika nanti mereka tidak lagi bekerja siapa yang akan mengajar anak-anak berkebutuhan khusus.

Tujuan dalam penelitian ini adalah untuk menguji apakah terdapat hubungan antara komitmen organisasi dengan kinerja pada guru pendidik khusus honorer (GPK) Di Kota Padang.

\section{Tinjauan Pustaka}

\subsection{Pengetian Kinerja}

Mangkunegara (dalam, Setiawan 2017) menyatakan kinerja adalah prestasi kerja atau prestasi sesungguhnya yang dicapai oleh seseorang dari kualitas, kuntitas, dan ketepatan waktu yang dicapai oleh seorang pegawai dalam melaksanakaan tugasnya sesuai dengan tanggung jawab yang diberikan kepadanya. ${ }^{[8]}$.

Menurut Robbins (dalam Sapitri, 2016) mengemukakan komitmen organisasi adalah sebagai suatu keadaan dimana seorang individu memihak organisasi serta tujuan-tujuan dan keinginan untuk mempertahankan keanggotaanya dalam organisasi. ${ }^{[9]}$.

\subsection{Dimensi Kinerja}

Menurut Bernadin \& Russel (dalam Sapitri, 2016) ada beberapa dimensi dari kinerja yakni :

a. Kuantitas merupakan jumlah kerja yang dilakukan dalam suatu periode yang ditentukan.

b. Kualitas merupakan kualitas kerja yang dicapai berdasarkan syarat keseuaian dan kecapaianya.

c. Pengetahuan Kerja merupakan luasnya pengetahuan mengenai pekerjaan dan keterampilannya.

d. Kerja Sama merupakan kesediaan untuk bekerja sama dengan orang lain (sesama anggota organisasi)

e. Dapat diandalkan merupakan kesadaran dan dapat dipercaya dalam hal kehadiran dan penyelesaian pekerjaan

f. Inisiatif merupakan semangat untuk melaksanakan tugas-tugas baru dan dalam memperbesar tanggung jawabnya 
g. Sikap merupakan kepribadian,kepemimpinan,keramah-tamahan dan integritas pribadi.

\subsection{Komitmen Organisasi}

Menurut Robbins (dalam Sapitri, 2016) mengemukakan komitmen organisasi adalah sebagai suatu keadaan dimana seorang individu memihak organisasi serta tujuan-tujuan dan keinginan untuk mempertahankan keanggotaanya dalam organisasi. ${ }^{[9]}$.

\subsection{Komponen-komponen Komitmen Organisasi}

Menurut Allen dan Mayer (dalam Sopiah, 2008) komponen komitmen organisasi sebagai berikut ${ }^{[10]}$ :

1. Affective commitment yaitu terjadi apabila karyawan ingin menjadi bagian dari karena adanya ikatan emosional.

2. Continuance commitmen yaitu apabila karyawan tetap bertahan pada suatu organisasi karena membutuhkan gaji dan keuntungan-keuntungan lain,atau karena karyawan tersebut tidak menemukan pekerjaan lain.

3. Normative commitment yaitu timbul dari nilai-nilai dalam diri karyawan. Karyawan bertahan menjadi anggota organisasi karena adanya kesadaran bahwa komitmen terhadap organisasi merupakan hal yang seharusnya dilakukan

\section{Metodologi}

Alat ukur yang digunakan dalam penelitian ini adalah skala kepuasan kerja dan skala kompensasi.Menurut Azwar (2014) ${ }^{[1]}$, skala adalah daftar pernyataan yang akan mengungkap performansi yang menjadi karakter tipikal pada subjek yang diteliti, yang akan dimunculkan dalam bentuk respon-respon terhadap situasi yang dihadapi. Skala dalam penelitian ini memiliki format respon dengan empat alternatif jawaban. Skala yang digunakan dalam penelitian ini menggunakan format respon jawaban model Likert. Menurut Sugiyono (2014) ${ }^{[9]}$ skala Likert digunakan untuk mengukur sikap, pendapat, dan persepsi seseorang atau sekelompok orang tentang fenomena sosial.

Sampel adalah bagian dari populasi yang menjadi objek penelitian dengan tujuan agar sampel yang diambil dari populasinyare presentative atau mewakili sehingga dapat diperoleh informasi yang cukupuntukmengestimasipopulasinya (Sugiyono, 2014) ${ }^{[9]}$. Teknik sampling sampling jenuh yaitu yaitu cara penentuan sampel bila jumlah populasi relatif kecil,kurang dari 30 orang,atau penelitian yang ingin membuat generelisasi dengan kesalahan yang sangat kecil Sugiyono (2017) .Jumlah sampel sebanyak 86 orang gurupendidik khusus honorer (GPK) di Kota Padang.

\section{Hasil dan Diskusi}

\subsection{Hasil Penelitian}

Penelitian dilakukan dengan menyebarkan skala kepuasan kerja dan skala kompensasi. Pengambilan data dimulai pada hari Rabu tanggal 18 Desember 2018. Skala yang telah 
di isi oleh Guru Pendidik Khusus Honorer (GPK) di Kota Padang dikembalikan kepada peneliti.

Sebelum melakukan uji hipotesis terlebih dahulu peneliti melakukan uji asumsi terhadap data hasil penelitian yang meliputi uji normalitas sebaran dan uji linieritas hubungan antar variabel penelitian.

\subsubsection{Uji Normalitas}

Uji normalitas digunakan untuk mengetahui apakah populasi data berdistribusi normal atau tidak. Uji normalitas dalam penelitian ini menggunakan uji Kolmogorov-Smirnov. Data yang dinyatakan berdistribusi normal jika signifikansi (p) lebih besar dari 0,05 . Priyatno $(2008)^{[5]}$ menyatakan bahwa data dinyatakan berdistribusi normal jika signifikansi lebih besar dari 5\% atau 0,05.Berdasarkanhasil pengolahan data dengan menggunakan program IBM SPSS versi 21.0, maka diperoleh hasil sebagai berikut:

Tabel 1 : Uji Normalitas Skala Kepuasan Kerja dengan Kompensasi

\begin{tabular}{|l|c|c|c|c|}
\hline \multicolumn{1}{|c|}{ Variabel } & $\mathrm{N}$ & $\mathrm{KSZ}$ & $\mathrm{p}$ & Sebaran \\
\hline $\begin{array}{l}\text { Komimten } \\
\text { Organisasi }\end{array}$ & 86 & 0,858 & 0,453 & Normal \\
\hline Kinerja & 86 & 1,005 & 0,267 & Normal \\
\hline
\end{tabular}

Berdasarkan tabel 1 di atas, maka diperoleh nilai signifikansi pada skala komitmen organisasi sebesar $\mathrm{p}=0,858$ dengan $\mathrm{KSZ}=0,453$ hasil tersebut menunjukan bahwa nilai $\mathrm{p}>0,05$, artinya sebaran skala komitmen organisasi terdistribusi secara normal, sedangkan untuk kinerja diperoleh nilai signifikansi sebesar $\mathrm{p}=0,267$ dengan $\mathrm{KSZ}=1,005$ hasil tersebut menunjukan bahwa nilai $\mathrm{p}$ $>0,05$, artinya sebaran skala kinerja terdistribusi secara normal.

\subsubsection{Uji Linieritas}

Uji linieritas bertujuan untuk mengetahui apakah dua variabel mempunyai hubungan yang linier atau tidak. Dua variabel dikatakan mempunyai hubungan yang linier bila signifikansi (Linearity) kurang dari 0,05 (Priyatno, 2008) ${ }^{[5]}$. Berdasarkan hasil pengolahan data dengan menggunakan program IBM SPSS21.0, maka diperoleh hasil sebagai berikut:

Tabel 2 : Uji Linieritas Skala Kepuasan Kerja denganKompensasi

\begin{tabular}{|c|c|c|c|c|}
\hline $\mathrm{N}$ & Df & Mean Square & F & Sig \\
\hline 78 & 1 & 2690,779 & 553,532 & .000 \\
\hline
\end{tabular}

Berdasarkan tabel 2 di atas, diperoleh nilai $F=553,532$ dengan signifikansi sebesar $\mathrm{p}=0,000(\mathrm{p}<0,05)$, artinya varians pada skala kompensasi dengan kepuasan kerja tergolong linier.

\subsubsection{Uji Hipotesis}

Uji hipotesis bertujuan untuk mengetahui apakah kesimpulan pada sampel dapat berlaku untuk populasi atau dapat digeneralisasi (Priyatno, 2008) ${ }^{[5]}$. Pengolahan data penelitian tentang hubungan antara komitmen organisasi dengan kinerja 
Guru Pendidik KhususHonorer (GPK) kepada 86 orang guru di Kota Padang menggunakanuji statistic Pearson Product Moment dengan bantuan SPSS 21,0.Hasil perhitungan uji korelasi Product Moment (Pearson) dengan bantuan SPSS 21,0dapat dilihat pada tabel 3 sebagai berikut :

Tabel3 :Hasil Uji Korelasi Antara Skala SkalaKompensasi dengan Kepuasan Kerja

\begin{tabular}{|c|c|c|c|l|}
\hline $\mathrm{P}$ & $(\alpha)$ & Nilai Korelasi $(\mathrm{r})$ & $\mathrm{R}$ square & \multicolumn{1}{c|}{ Kesimpulan } \\
\hline 0,000 & 0.01 & 0,698 & 0,487 & $\begin{array}{l}\text { sig }(2 \text { - tailed) } 0,000<0,01 \\
\text { level of significant }(\alpha), \text { berarti } \\
\text { hipotesis diterima. }\end{array}$ \\
\hline
\end{tabular}

Berdasarkan tabel di atas, maka diperoleh koefisien korelasi antara kommitmen organisasi dengan kinerja yaitu sebesar $r=0,698$. Hal ini menunjukkan adanya korelasi yang berarah positif, yang artinya semakin tinggi komitmen organisasi maka kinerja semakin tinggi. Begitu juga sebaliknya, semakin rendah komitmen organisasi maka kinerja semakin rendah. Hal ini di perkuat dengan hasil uji signifikan dengan bantuan IBM SPSS 21,0 didapatkan $p=0,000<0,01$ level of significant $(\alpha)$, sesuai dengan hipotesis diterima, bahwa terdapat hubungan antara Komitmen organisasi dengan Kinerja Guru Pendidik Khusus Honorer (GPK) di Kota Padang.

Berikut tabel deskriptif statisitik dari variabel kompensasi dan kepuasan kerja berdasarkan Mean Hipotetik sebagai berikut:

Tabel4 :Deskriptif Statisitik Mean Hipotetik

\begin{tabular}{|l|c|c|c|c|c|}
\hline \multicolumn{1}{|c|}{ Variabel } & $\mathrm{N}$ & Mean & Std.Deviation & Minimum & Maximum \\
\hline Kompensasi & 86 & 72,93 & 10,013 & 87 & 187 \\
\hline Kinerja & 86 & 145,27 & 22,663 & 57 & 94 \\
\hline
\end{tabular}

Berdasarkan tabel 4 diatas nilai Mean Hipotetik, maka dapat dilakukan pengelompokkan yang mengacu pada kriteria pengka tegorisasian dengan tujuan menempatkan individu kedalam kelompok-kelompok yang terpisah secara berjenjang menurut suatu kontinum berdasarkan atribut yang diukur (Azwar, 2014) $)^{[1]}$, dengan ketentuan sebagai berikut :

Tabel5 :Norma Kategorisasi

\begin{tabular}{|c|c|}
\hline Norma & Kategorisasi \\
\hline$X<(\mu-1,0 \sigma)$ & Rendah \\
\hline$(\mu-1,0 \sigma) \leq X<(\mu+1,0 \sigma)$ & Sedang \\
\hline$(\mu+1,0 \sigma) \leq X$ & Tinggi \\
\hline
\end{tabular}

Keterangan : 
Riris Wisuda Tumanggor, Krisnova Nastasia

Jurnal PSYCHE 165 Vol 12 No 2 (2019) 174-182

$\begin{array}{ll}\mathrm{X} & : \text { Skor mentah sampel } \\ \mu & : \text { Mean atau rata-rata } \\ \sigma & : \text { Standar Deviasi }\end{array}$

Berdasarkan norma diatas, maka diperoleh kategorisasi subjek penelitian pada variabel kompensasi dan kepuasan kerja sebagai berikut:

Tabel6 :Kategori Komitmen organisasi dengan kinerja

\begin{tabular}{|c|c|c|c|c|}
\hline \multirow{2}{*}{ Variabel } & Skor & Jumlah & Persentase (\%) & Kategori \\
\hline \multirow{3}{*}{ Komitmen organisasi } & $57-62$ & 13 & $15 \%$ & Rendah \\
\cline { 2 - 5 } & $63-82$ & 60 & $70 \%$ & Sedang \\
\cline { 2 - 5 } & $83-94$ & 13 & $15 \%$ & Tinggi \\
\hline \multirow{3}{*}{ Kinerja } & $87-121$ & 7 & $8 \%$ & Rendah \\
\cline { 2 - 5 } & $122-167$ & 63 & $73 \%$ & Sedang \\
\cline { 2 - 5 } & $168-187$ & 16 & $19 \%$ & Tinggi \\
\hline
\end{tabular}

Berdasarkan tabel di atas dapat digambarkan bahwa ada $15 \%$ Guru yang memiliki ko mitmen organisasi dengan kategori rendah, $70 \%$ Guru yang memiliki komitmen organisasi dengan kategori sedang dan $15 \%$ Guru memiliki komitmen organisasi dengan kategori tinggi.Sementara itu ada $8 \%$ Guru yang memiliki kinerja dengan kategori rendah, 73\% Guru yang memiliki kinerja dengan kategori sedang dan 19\% Guru yang memiliki kinerja pada kategori tinggi.

\section{Sumbangan Efektif}

Besar sumbangan variabel kompensasi terhadap variabel kepuasan kerja dapat ditentukan dengan menggunakan rumus koefisien determinan. Koefisien determinan adalah kuadarat dari koefisien korelasi yang dikali dengan $100 \%$ (Priyatno, 2008) ${ }^{[5]}$.

Derajat koefisien determinan dicari dengan menggunakan rumus sebagai berikut :

$$
\mathrm{KP}=\mathrm{r}^{2} .100 \%
$$

Keterangan:

$\mathrm{KP}=$ Nilai Koefisien Determinan

$\mathrm{r} \quad=$ Nilai Koefisien Korelasi

$\mathrm{KP}=\mathrm{r}^{2} \times 100 \%$

$$
\begin{aligned}
& =0,698^{2} \times 100 \% \\
& =487.204 \times 100 \% \\
& =48,72 \% \\
& =49 \%
\end{aligned}
$$

Berdasarkan rumus tersebut maka dapat ditentukan bahwa besarnya sumbangan komitmen organisasi terhadap kepuasan kerja adalah sebesar $49 \%$ dan $51 \%$ lagi dipengaruhi oleh faktor lain. 
Berdasarkan hasil uji korelasi Product Moment (Pearson) yang dilakukan dengan bantuan IBM SPSS versi 21.0, dimana level of significant $(\alpha)$ 0,01 dan diperoleh nilai koefisien korelasi $\left(\mathrm{r}_{\mathrm{xy}}\right)=0,698$ dengan nilai $(\mathrm{p})$ sig $=0,000$, karena nilai $(\mathrm{p})$ sig $0,000<0,01$ maka hipotesis diterima. Hasil ini menunjukkan bahwa terdapat hubungan antara kompitmen organisasi dengan kinerja pada Guru Pendidik Khusus honorer (GPK) di Kota Padang dengan arah positif. Artinya semakin tinggi komitmen organisasi maka kinerja semakin tinggi . Begitu juga sebaliknya, semakin rendah komitmen organisasi Guru Pendidik Khusus (GPK) di Kota Padang maka kinerja semakin rendah.

Menurut pendapat dari Sinambela (dalam Priansa, $2017{ }^{[4]}$ Kinerja pegawai yang baik juga tentunya dapat mendorong tercapainya tujuan-tujuan organisasi. Itulah sebabnya mengapa kinerja pegawai sangat penting untuk kemajuan sebuah organisasi atau instansi. Hal ini menyatakan bahwa kinerja adalah kemampuan pegawai dalam melakukan keahlian tertentu. Kinerja pegawai sangatlah perlu sebab dengan kinerja ini akan diketahui seberapa jauh kemampuan pegawai dalam melaksanakan tugas yang dibebankan kepadanya.

Komitmen organisasi memberikan kontribusi terhadap kinerja sebesar 49\%. sedangkan $51 \%$ sisanya dipengaruhi oleh faktor-faktor lain. Menurut Mahmuldi (dalam Salbiah, 2017) [6] faktor-faktor yang dapat mempengaruhi kinerja adalah ${ }^{7]}$, faktor personal, fakotr kepemimpinan, faktor tim, fakotr sisitim dan faktor kontekstualBerdasarkan hasil penelitian maka didapatkan hasil bahwa ada $15 \%$ Guru yang memiliki komitmen organisasi dengan kategori rendah, $70 \%$ Guru yang memiliki komitmen organisasi dengan kategori sedang dan 15\% Guru memiliki komitmen organisasi dengan kategori tinggi.

Sementara itu ada $8 \%$ Guru yang memiliki kinerjadengan kategori rendah, 73\% Guru yang memiliki kinerja dengan kategori sedang dan $13 \%$ Guru yang memiliki kinerja pada kategori tinggi.

\section{Kesimpulan}

Berdasarkan hasil analisis data kuantitatif yang diperoleh melalui penelitian ini maka dapat diperoleh kesimpulan bahwa hubungan antara komitmen organisasi dengan kinerja Guru Pendidik Khusus Honorer (GPK) dengan arah positif dan signifikan. Terlihat dari hasil korelasi antara antara kinerja dengan komitmen organisasi pada Guru Pendidik Khusus Honorer (GPK) di Kota Padang dengan arah positif, artinya hipotesis diterima jika komitmen organisasi tinggi, maka kinerja guru akan tinggi, sebaliknya jika komitmen organisasi diberikan rendah, maka kinerja guru akan rendah.

Besarnya sumbangan efektif dari variabel komitmen organisasi dengan kinerja pada Guru Pendidik Khusus Honorer (GPK) di Kota Padang adalah sebesar 49\%.

\section{Referensi}

[1] Azwar, Syaifudin. 2014. Penyusunan Skala Psikologi. Yogyakarta: Pustaka Pelajar.

[2] Ashar, Suyoto, Munandar. 2008.Psikologi Industri dan Organisasi. Jakarta: UI Press.

[3] Devi, Afrina Marti. 2012. Pendidikan Inklusif Disekolah Dasar Kota Padang. Jurnal Ilmiah Pendidikan Khusus. Vol 1 No. 3, September 2012. Padang: Jurusan Pendidikan Luar Biasa FIP Universitas Negeri Padang.

[4] Priansa, Donni Juni. 2017. Manajemen Kinerja Kepegawaian. Bandung: Pustaka Setia.

[5] Priyatno, Dwi. 2008. Mandiri Belajar SPSS untuk Analisis Data dan Uji Statistik. Jakarta: Mediakom.

[6] Salbiyah \& Budi wahyu. 2017. Pengaruh Motivasi Kerja Terhadap Kinerja Tenaga Kependidikan Universitas Muhammadiyah Surabaya Tahun 2016. Jurnal Ekonomi \& 
Riris Wisuda Tumanggor, Krisnova Nastasia

Jurnal PSYCHE 165 Vol 12 No 2 (2019) 174-182

Bisnis. Vol 14 No. 2, Juli 2017.Surabaya: Fakultas Ekonomi \& Bisnis Universitas Muhammadiyah Surabaya.

[7] Sapitri, Ranty. 2016. Pengaruh Komitmen Organisasi Terhadap Kinerja Karyawan Perusahaan Listrik Negara Area Pekanbaru. Jurnal Administrasi Bisnis Fakultas Ilmu Sosial dan Ilmu Politik. Vol 3 No. 2, Oktober 2016.Riau: Program Studi Ilmiah Administrasi Bisnis FISIP Universitas Riau.

[8] Setiawan, Kiki Cahaya. 2015. Pengaruh Motivasi Kerja Terhadap Kinerja Karwayan Level Pelaksana di Divisi Operasi PT. Pusri Palembang. Jurnal Psikologi Islami. Vol 1 No. 2. Palembang: Universitas Islam Negeri Fatah Palembang.

[9] Sopiah. 2008. Perilaku Organisasional. Yogyakarta: Andi Offset Zakia , Dieni

[10] Sugiyono. 2014. Metode Penelitian Kualitatif dan Kuantitatif. Bandung: CV Alfabet. 